\title{
Assessment of Environmental Radioactivity in Soil Samples from Kathmandu Valley, Nepal
}

\section{P. Lamichhane, B. Rijal, P. Shrestha and B. R. Shah}

Journal of Nepal Physical Society

Volume 7, Issue 2, June 2021

ISSN: 2392-473X (Print), 2738-9537 (Online)

Editors:

Dr. Binod Adhikari

Dr. Bhawani Joshi

Dr. Manoj Kumar Yadav

Dr. Krishna Rai

Dr. Rajendra Prasad Adhikari

Mr. Kiran Pudasainee

JNPS, 7 (2), 89-96 (2021)

DOI: https://doi.org/10.3126/jnphyssoc.v7i2.38628

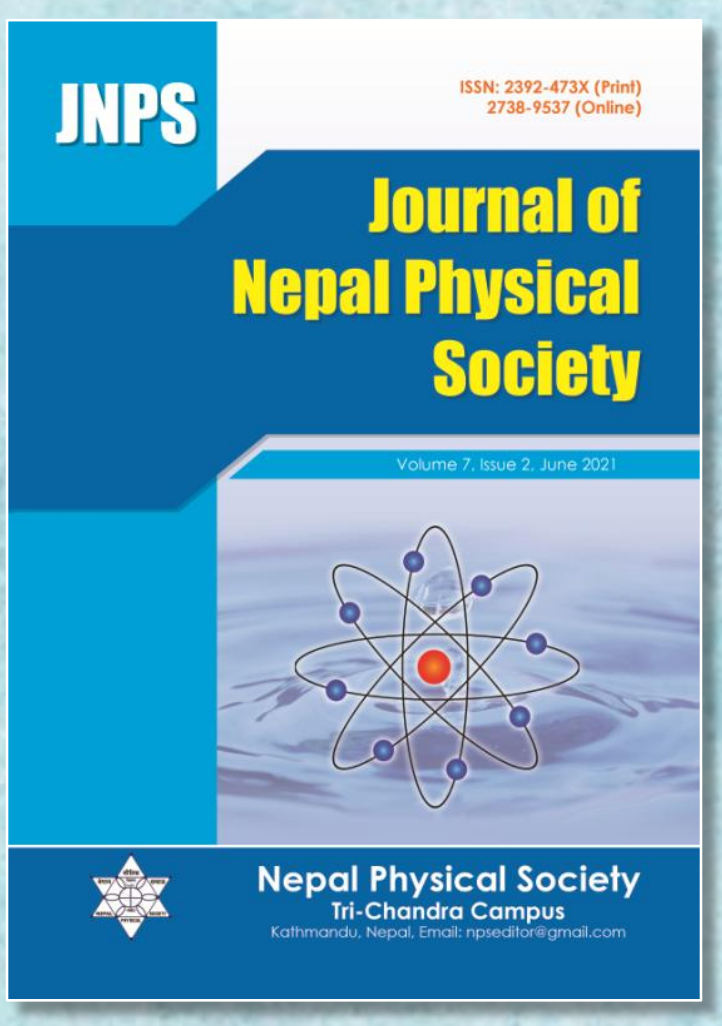

Published by:

Nepal Physical Society

P.O. Box: 2934

Tri-Chandra Campus

Kathmandu, Nepal

Email: nps.editor@gmail.com 


\title{
Assessment of Environmental Radioactivity in Soil Samples from Kathmandu Valley, Nepal
}

\author{
P. Lamichhane ${ }^{1,2}$, B. Rijal ${ }^{1}$, P. Shrestha ${ }^{2}$ and B. R. Shah ${ }^{1, *}$ \\ ${ }^{1}$ Physical Science Laboratory, Faculty of Science, Nepal Academy of Science and Technology, \\ Khumaltar, Lalitpur, Nepal \\ ${ }^{2}$ Department of Physics, Amrit Campus, Tribhuvan University, Kathmandu, Nepal \\ *Corresponding Email: buddharshah25@gmail.com
}

Received: 14 March, 2021; Revised: 15 April, 2021; Accepted: 20 June, 2021

\begin{abstract}
This study was conducted to determine the amount of naturally occurring radioactivity in the soil of Nepal's Kathmandu valley. The activity of naturally occurring radionuclides was determined in these soil samples using a sodium iodide detector. Activity concentrations of ${ }^{238} \mathrm{U},{ }^{232} \mathrm{Th}$, and ${ }^{40} \mathrm{~K}$ were found in the range: $32.00-111.38 \mathrm{~Bq} \mathrm{~kg}^{-1}, 33.52-130.04 \mathrm{~Bq} \mathrm{~kg}^{-1}$, and 342.50-897.71 $\mathrm{Bq} \mathrm{kg}^{-1}$, respectively. These values are well within the permissible range as recommended by UNSCEAR. The soil samples with the highest activity concentrations were primarily found in the valley's northern region. The activity concentrations were also used to calculate the radiation hazard indices: the mean value obtained were $96.63 \mathrm{nGy} \mathrm{hr}^{-1}$ for Absorbed Gamma Dose Rate in Air, $200.04 \mathrm{~Bq} \mathrm{~kg}^{-1}$ for Radium Equivalent Activity, the 0.12 $\mathrm{mSv} \mathrm{yr}^{-1}$ for Annual Effective Dose, and 0.55 for External Hazard Index. These calculated hazard indices were used to estimate the potential radiological health risk from the soil, and the dose rates associated with it were significantly less than their permissible limit. The overall findings indicate no radiological threat to the population's health in the study area. Additionally, the findings of this study provide baseline information on potential radionuclides that contribute mostly for radiation exposure from natural sources.
\end{abstract}

Keywords: Absorbed dose rates, Annual Effective Dose Rates, Environmental radioactivity, External Hazard Index, Radium Equivalent Activity

\section{INTRODUCTION}

Soil is one of the key sources of human exposure to ionizing radiation. There has recently been a growing demand for soil data and information. All rocks, soils and minerals contain radionuclides that occur naturally, for example, Potassium (K-40), Uranium (U), Thorium (Th) and their progenies [1]. The Uranium and Thorium decay chains found in nature are related to very long half lives of the parent of these chains. Naturally occurring radioactive compounds in the earth's crust are not uniformly distributed and their concentration levels in soil are extremely variable, which are influenced by local geology, altitude, weather, geochemistry, economic and technical activities carried by human, etc. of the region [2]. Uranium is a primordial radioactive element and it exists in nature as a set of three radioisotopes, with a relative abundance of ${ }^{238} \mathrm{U}(99 \%)$ with half life of $4.468 \times 10^{9}$ years, ${ }^{235} \mathrm{U}$ $(0.71 \%)$ with half life of $7.038 \times 10^{8}$ years and ${ }^{234} \mathrm{U}$ $(0.006 \%)$ having half life of $2.445 \times 10^{5}$ years [3]. It is both chemically toxic and radioactive. Because of its solubility in water, plants readily consume it through food chains and soil/water systems and eventually take place in human's food chain.

The most stable isotope, ${ }^{232} \mathrm{Th}$, has a half life of 14.05 billion years or the era of the universe. It slowly decays through alpha decay, beginning a sequence of decay termed the series of thorium ending at ${ }^{208} \mathrm{~Pb}$ [4]. Meanwhile ${ }^{40} \mathrm{~K}$ is a rare instance of an isotope undergoing both beta and gamma decay. It decays to ${ }^{40} \mathrm{Ca}$ with the emission of beta particle of up to $1.31 \mathrm{MeV}$ and antineutrino in approximately $89.28 \%$ of occurrences. It decays 
in about of $10.72 \%$ of the occurrences into ${ }^{40} \mathrm{Ar}$ by electron capture, with emission of neutrino and a gamma ray of energy $1.460 \mathrm{MeV}$ and very rarely $(0.001 \%)$ it decays by emitting a positron and neutrino and collapses to ${ }^{40} \mathrm{Ar}[5,6]$.

Various studies on natural radioactivity and dose rate have been conducted in different regions of Nepal. According to the literature, radionuclide ${ }^{40} \mathrm{~K}$ has been assessed in the soil of Kathmandu valley using gamma spectroscopy indicating that the northern portion of the valley having higher activity than the southern portion and the activity was in the range of $26 \mathrm{~Bq} / \mathrm{kg}$ to $716 \mathrm{~Bq} / \mathrm{kg}[7,8] .{ }^{40} \mathrm{~K}$ was determined in the northern part of the Kathmandu valley using gamma spectroscopy and atomic emission spectroscopy. The report indicated that the specific activity of water and soil samples ranged between $2.25-17.87 \mathrm{~Bq} / \mathrm{kg}$ and $17.48-412.26 \mathrm{~Bq} / \mathrm{kg}$, respectively [9]. The concentration of ${ }^{137} \mathrm{Cs}$ in Lichens and Moses was determined using a Multichannel Analyzer coupled to a $\mathrm{NaI}(\mathrm{Tl})$ detector system and was found to be $410 \mathrm{~Bq} / \mathrm{Kg}$ in Ramalina sp. from Ranipauwa; additionally, the study discovered a high concentration in samples collected from the DoodhPokhari watershed area in Kathmandu valley [10]. A reverse-electrode $\mathrm{Ge}$ detector was used to determine the natural radioactivity level of selected rocks in Hetauda. radioactivity levels are higher due to high content of uranium [13].

A bibliographic survey showed that no statistics were available for the Kathmandu valley, Nepal. Keeping that in focus, assessment of terrestrial radioactivity in Kathmandu's topsoil have been carried out and analyzed to determine their essential elements and possible radioactive elements and radionuclides that emit gamma by using digital gamma spectrometer coupled with a 14-PIN digiBASE PMT NaI Detector system. This study aims at providing assessment on radioactivity in the environment of Kathmandu valley due to radionuclides of uranium and thorium series and the potassium-40 in soil samples collected from various locations around the Kathmandu valley.

\section{MATERIALS AND METHODS}

\subsection{Study Area}

Kathmandu valley, the study site, is the capital city of Nepal with an area of $570 \mathrm{Km}^{2}$ spanning Kathmandu, Lalitpur and Bhaktapur districts [14]. A total of 30 locations within the valley assuming Ratnapark as centre were identified for sample collection. Site locations have been shown in figure (1). The details of site locations with their latitude and longitude are given in Table 1.

The specific activities of ${ }^{238} \mathrm{U}$ were found to be between 17 and $95 \mathrm{~Bq} / \mathrm{kg}$,

${ }^{232} \mathrm{Th}$ was found to be between 24 and $260 \mathrm{~Bq} / \mathrm{kg}$, and ${ }^{40} \mathrm{~K}$ was found to be between 32 and $541 \mathrm{~Bq} / \mathrm{kg}$. Additionally, this literature included dose rates absorbed in the air and annual effective dose, both of which are well below the UNSCEARrecommended level for the majority of samples, with the exception of Granite Schist 66, which has a dose rate of $1.57 \mathrm{mSv} / \mathrm{yr}$ [11].

Similarly, the HpGe detector was used to quantify the specific activity and hazard indices in soil samples of the Lambordia region in Northern Italy, eastern Haryana in India, the Republic of Srpska, and the Araba valley in Jordan. The results for Araba [2], Srpska [3], and Haryana [12] are similar compared to the global median and within the range of the UNSCEAR report, whereas the Lambordia region's

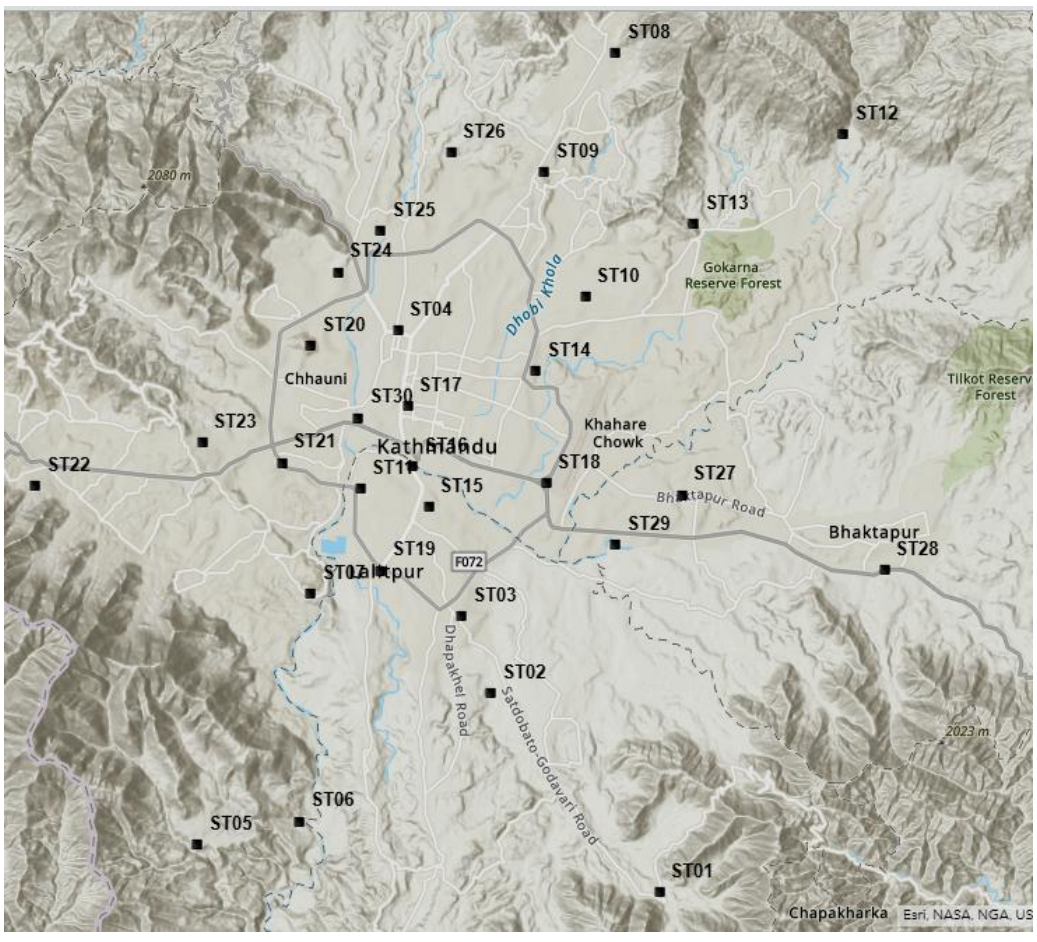

Fig. 1: Sampling stations (Courtsey: ArcGIS) 
Table1: Stations with latitude and longitude (Etrex Garmin H7262 GPS)

\begin{tabular}{|c|c|c|c|}
\hline Location's Local Name & Location Code & Latitude (North) & Longitude (East) \\
\hline Godawari & ST01 & $27^{\circ} 35^{\prime} 47.5^{\prime \prime}$ & $85^{\circ} 22^{\prime} 36.9^{\prime \prime}$ \\
\hline Harisiddhi & ST02 & $27^{\circ} 38^{\prime} 22.9^{\prime \prime}$ & $85^{\circ} 20^{\prime} 07.8^{\prime \prime}$ \\
\hline Satdobato & ST03 & $27^{\circ} 39^{\prime} 23.6^{\prime \prime}$ & $85^{\circ} 19^{\prime} 41.7^{\prime \prime}$ \\
\hline Thamel & ST04 & $27^{\circ} 43^{\prime} 06.5^{\prime \prime}$ & $85^{\circ} 18^{\prime} 46.0^{\prime \prime}$ \\
\hline Dakxinkali & ST05 & $27^{\circ} 36^{\prime} 24.7^{\prime \prime}$ & $85^{\circ} 15^{\prime} 48.1 ”$ \\
\hline Pharping & ST06 & $27^{\circ} 36^{\prime} 43.1^{\prime \prime}$ & $85^{\circ} 17^{\prime} 18.8^{\prime \prime}$ \\
\hline Chobhar & ST07 & $27^{\circ} 39^{\prime} 40.9^{\prime \prime}$ & $85^{\circ} 17 ’ 28.3^{\prime \prime}$ \\
\hline Budanilkantha & ST08 & $27^{\circ} 46^{\prime} 43.7^{\prime \prime}$ & $85^{\circ} 21^{\prime} 58.2^{\prime \prime}$ \\
\hline Bansbari & ST09 & $27^{\circ} 45^{\prime} 10.0^{\prime \prime}$ & $85^{\circ} 20^{\prime} 55.1 ”$ \\
\hline Chabahil & ST10 & $27^{\circ} 43^{\prime} 32.9^{\prime \prime}$ & $85^{\circ} 21^{\prime} 31.2^{\prime \prime}$ \\
\hline Sanepa & ST11 & $27^{\circ} 41^{\prime} 03.3^{\prime \prime}$ & $85^{\circ} 18^{\prime} 12.6^{\prime \prime}$ \\
\hline Sundarijal & ST12 & $27^{\circ} 45^{\prime} 40.2^{\prime \prime}$ & $85^{\circ} 25^{\prime} 19.6^{\prime \prime}$ \\
\hline Gokarna & ST13 & $27^{\circ} 44^{\prime} 29.9^{\prime \prime}$ & $85^{\circ} 23^{\prime} 07.3^{\prime \prime}$ \\
\hline Pasupati & ST14 & $27^{\circ} 42^{\prime} 35.2^{\prime \prime}$ & $85^{\circ} 20^{\prime} 47.3^{\prime \prime}$ \\
\hline Patandhoka & ST15 & $27^{\circ} 40^{\prime} 48.8^{\prime \prime}$ & $85^{\circ} 19^{\prime} 13.1 "$ \\
\hline Kupandol & ST16 & $27^{\circ} 41^{\prime} 20.2^{\prime \prime}$ & $85^{\circ} 18^{\prime} 58.7^{\prime \prime}$ \\
\hline Tundikhel & ST17 & $27^{\circ} 42^{\prime} 07.2^{\prime \prime}$ & $85^{\circ} 18^{\prime} 54.4^{\prime \prime}$ \\
\hline Tinkune & ST18 & $27^{\circ} 41^{\prime} 07.0^{\prime \prime}$ & $85^{\circ} 20^{\prime} 56.8^{\prime \prime}$ \\
\hline Ekantakuna & ST 19 & $27^{\circ} 39^{\prime} 58.9^{\prime \prime}$ & $85^{\circ} 18^{\prime} 30.1^{\prime \prime}$ \\
\hline Swayambhu & ST20 & $27^{\circ} 42^{\prime} 54.8^{\prime \prime}$ & $85^{\circ} 17^{\prime} 28.5^{\prime \prime}$ \\
\hline Khasibazar & ST21 & $27^{\circ} 41^{\prime} 23.3^{\prime \prime}$ & $85^{\circ} 17^{\prime} 03.2^{\prime \prime}$ \\
\hline Chandragiri & ST22 & $27^{\circ} 41^{\prime} 04.9^{\prime \prime}$ & $85^{\circ} 13^{\prime} 24.9^{\prime \prime}$ \\
\hline Old Naikap & ST23 & $27^{\circ} 41^{\prime} 39.0^{\prime \prime}$ & $85^{\circ} 15^{\prime} 53.0^{\prime \prime}$ \\
\hline Bohoratar & ST 24 & $27^{\circ} 43^{\prime} 52.2^{\prime \prime}$ & $85^{\circ} 17^{\prime} 52.4^{\prime \prime}$ \\
\hline Balaju(Gumba) & ST25 & $27^{\circ} 44^{\prime} 24.7^{\prime \prime}$ & $85^{\circ} 18^{\prime} 30.1^{\prime \prime}$ \\
\hline Tokha(Housing) & ST 26 & $27^{\circ} 45^{\prime} 26.0^{\prime \prime}$ & $85^{\circ} 19^{\prime} 33.0^{\prime \prime}$ \\
\hline Sanothimi & ST27 & $27^{\circ} 40^{\prime} 58.0^{\prime \prime}$ & $85^{\circ} 22^{\prime} 56.6^{\prime \prime}$ \\
\hline Suryabinayak & ST28 & $27^{\circ} 39^{\prime} 59.4^{\prime \prime}$ & $85^{\circ} 25^{\prime} 56.1 ”$ \\
\hline Kausaltar & ST29 & $27^{\circ} 40^{\prime} 19.6 \prime$ & $85^{\circ} 21^{\prime} 57.7^{\prime \prime}$ \\
\hline Teku(Paropakar) & ST30 & $27^{\circ} 41^{\prime} 58.2^{\prime \prime}$ & $85^{\circ} 18^{\prime} 10.7^{\prime \prime}$ \\
\hline
\end{tabular}

\subsection{Sample Collection and Preparation}

Three soil samples from each station at depth 14-15 $\mathrm{cm}$ were taken randomly within a circle of $1 \mathrm{~m}$ diameter dug in the location. A total of 90 specimens were taken by removing the vegetation on the surface level of the floor. The samples were collected in the plastic bags with the help of hoe and shovel, and the packet containing the sample was labeled and secured after sampling. Soils having high earthworm activity and rodent activity were avoided because of uneven mixing of the soil to considerable depth $[15,16]$. The samples were then kept in the sun rays to remove any moisture and short living radionuclides for half of month. The samples were then crushed to pass through 2 $\mathrm{mm}$ sieve, homogenized, and harmonically sealed for one month in the zipper storage bag to attain radioactive equilibrium.

\subsection{Sample Analysis}

A representative sample of $500 \pm 5$ gram was kept inside a GA-MA 133N Marinelli beaker whose 
geometry allows $4 \pi$ symmetry. The detection of sample was performed using 3"x3" $\mathrm{NaI}(\mathrm{Tl})$ (ORTEC) scintillation detector coupled to a pc based 14-pin digiBASE photo-multiplier tube. The system comprises a miniaturized preamplifier and detector high voltage $(0 \mathrm{~V}$ to $+1200 \mathrm{~V}$ bias in steps of $1.25 \mathrm{~V}$ under computer control) with a powerful digital multichannel analyzer and special features for fine-time resolution measurements, all incorporated into a lightweight $(287 \mathrm{gm})$, compact (63 $\mathrm{mm}$ diameter-87 $\mathrm{mm}$ length) tube base with a USB connection [17]. Gamma Vision-version 8 software was used for this study providing time of analysis of 3600 seconds of live time for each sample. The gamma spectrometer used for the analysis has detector with relative efficiency of $4.03 \%$ and a resolution at full width at half maximum (FWHM) of $48.54 \mathrm{keV}$ at $778.90 \mathrm{keV}$ of ${ }^{152} \mathrm{Eu}$. A heavy lead shield $\left({ }^{210} \mathrm{~Pb}<50 \mathrm{~Bq} / \mathrm{kg}\right)$ with a thickness of around $5 \mathrm{~cm}$ enclosed the detector to eliminate background interference. Following a count time of 3600 seconds for each sample, ${ }^{238} \mathrm{U}$ activity concentration was estimated through its daughter nuclide ${ }^{214} \mathrm{Bi}$ at $609.312 \mathrm{keV}$ and ${ }^{214} \mathrm{~Pb}$ at $351.932 \mathrm{keV}[17,18] .{ }^{232} \mathrm{Th}$ activity concentration was calculated through its daughter nuclei ${ }^{212} \mathrm{~Pb}$ at $238.632 \mathrm{keV}$ and ${ }^{228} \mathrm{Ac}$ at $911.196 \mathrm{keV}[18,19] .{ }^{40} \mathrm{~K}$ activity was measured through direct transition at $1.46 \mathrm{MeV}[18,19]$.

\section{RESULTS AND DISCUSSION}

\subsection{Activity Concentration}

The activity concentration of ${ }^{40} \mathrm{~K},{ }^{238} \mathrm{U}$ and ${ }^{232} \mathrm{Th}$ along with deviation in concentration within soils from particular location has been given in table 2 . ${ }^{40} \mathrm{~K}$ activity concentration ranged from 409.99 $\mathrm{Bq} / \mathrm{kg}$ to $814.13 \mathrm{~Bq} / \mathrm{kg}$ with average of 592.46 $\mathrm{Bq} / \mathrm{kg}$. The lowest ${ }^{40} \mathrm{~K}$ level was found in soil samples of station 23 and highest in samples of station $10 .{ }^{238} \mathrm{U}$ activity concentration ranged from $35.43 \mathrm{~Bq} / \mathrm{kg}$ to $97.09 \mathrm{~Bq} / \mathrm{kg}$ with an average of $59.06 \mathrm{~Bq} / \mathrm{kg}$. The lowest and highest ${ }^{238} \mathrm{U}$ has been found in station 7 and station 16 respectively. Similarly the activity concentration of ${ }^{232} \mathrm{Th}$ ranged from $35.58 \mathrm{~Bq} / \mathrm{kg}$ to $115.15 \mathrm{~Bq} / \mathrm{kg}$ with mean of $69.59 \mathrm{~Bq} / \mathrm{kg}$. Soils from station 23 and station 10 were found to have lowest and highest ${ }^{232} \mathrm{Th}$ activity concentration respectively. The activity concentrations of all the radionuclides of all the soil samples were found above worldwide average for them respectively, i.e. $400 \mathrm{~Bq} / \mathrm{kg}$ for ${ }^{40} \mathrm{~K}, 35 \mathrm{~Bq} / \mathrm{kg}$ for ${ }^{238} \mathrm{U}$ and $30 \mathrm{~Bq} / \mathrm{kg}$ for ${ }^{232} \mathrm{Th}$ [20]. The average activity concentrations for ${ }^{40} \mathrm{~K}$, ${ }^{238} \mathrm{U}$ and ${ }^{232} \mathrm{Th}$ have been found $1.48,1.69$ and 2.32 times higher than worldwide average values for the respective radionuclides. A typical spectrum recorded for a soil sample on digiBASE spectrometer indicating radionuclides of interest has been shown in figure (2).

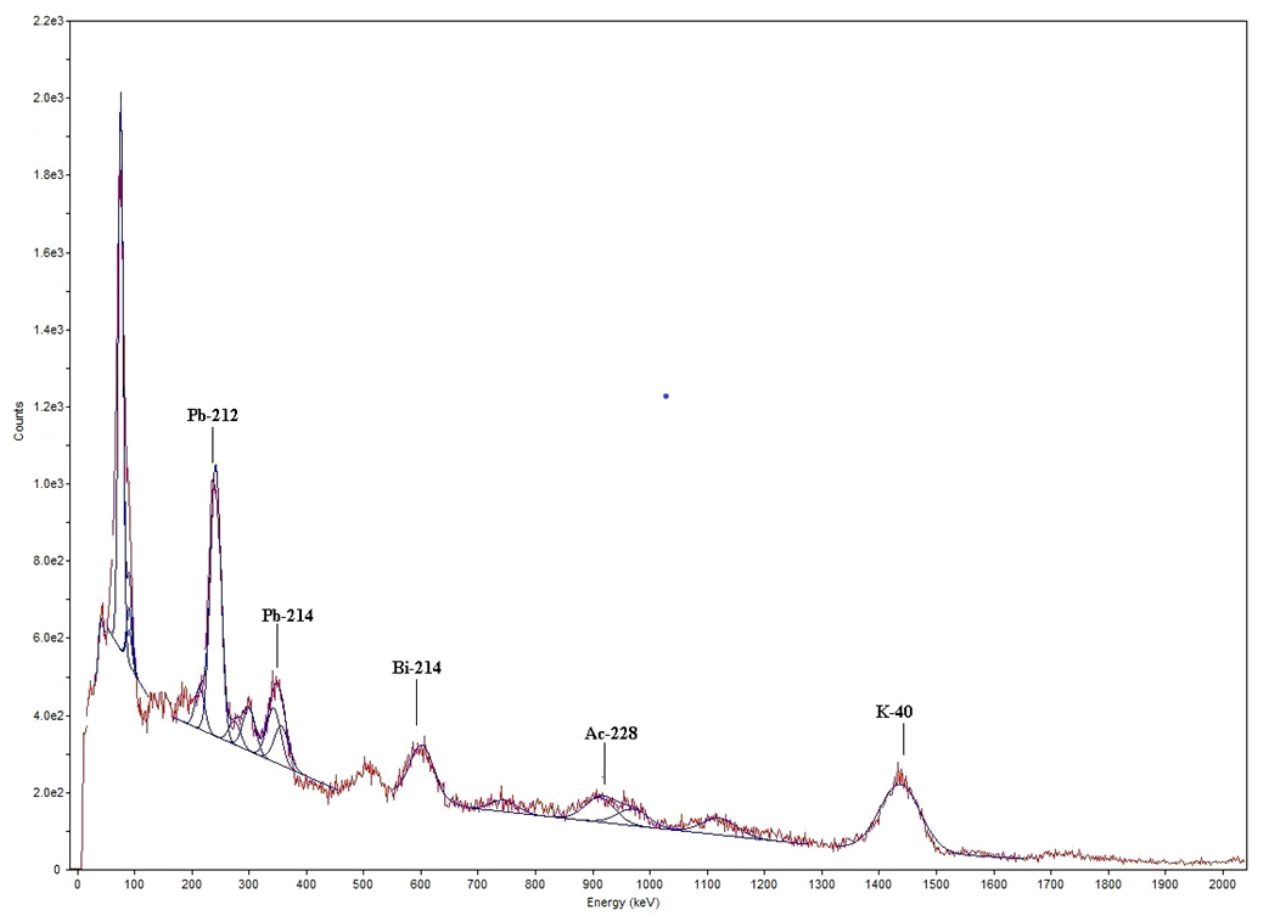

Fig. 2: Analyzed photo-peaks of a soil sample recorded on digiBASE Spectrometer. 
Table 2: Activity Concentrations, Dose Rates, Radium Equivalent and Effective Dose due to radionuclides in soil samples

\begin{tabular}{|c|c|c|c|c|c|c|c|}
\hline \multirow[b]{2}{*}{ S.N. } & \multirow[b]{2}{*}{ Location } & \multicolumn{3}{|c|}{ Concentrations in Soil $(\mathrm{Bq} / \mathrm{kg}) \pm \sigma$} & \multirow{2}{*}{$\begin{array}{c}\text { Absorbed } \\
\text { Dose } \\
\text { Rate } \\
\text { (nGy/hr) }\end{array}$} & \multirow{2}{*}{$\begin{array}{c}\text { Radium } \\
\text { Equivalent } \\
\text { (Bq/kg) }\end{array}$} & \multirow{2}{*}{$\begin{array}{c}\text { Annual } \\
\text { Effective } \\
\text { Dose } \\
(\mathrm{mSv} / \mathrm{yr})\end{array}$} \\
\hline & & $40 K$ & $238 U$ & 232Th & & & \\
\hline 1 & ST 01 & $591.69 \pm 53.93$ & $47.06 \pm 2.36$ & $86.26 \pm 4.33$ & 102.54 & 211.83 & 0.13 \\
\hline 2 & ST 02 & $526.66 \pm 26.85$ & $41.17 \pm 4.28$ & $82.13 \pm 8.50$ & 94.52 & 195.48 & 0.12 \\
\hline 3 & ST 03 & $531.66 \pm 5.12$ & $36.52 \pm 2.31$ & $78.81 \pm 8.26$ & 90.52 & 186.43 & 0.11 \\
\hline 4 & ST 04 & $491.98 \pm 81.84$ & $65.56 \pm 3.56$ & $82.8 \pm 11.40$ & 104.00 & 218.40 & 0.13 \\
\hline 5 & ST 05 & $458.45 \pm 30.43$ & $48.41 \pm 2.20$ & $81.36 \pm 5.04$ & 94.26 & 196.85 & 0.12 \\
\hline 6 & ST 06 & $705.85 \pm 53.52$ & $39.42 \pm 5.84$ & $52.22 \pm 3.56$ & 81.37 & 163.50 & 0.10 \\
\hline 7 & ST 07 & $597.49 \pm 10.97$ & $35.43 \pm 1.15$ & $58.53 \pm 17.74$ & 79.31 & 160.95 & 0.10 \\
\hline 8 & ST 08 & $740.72 \pm 23.34$ & $63.99 \pm 1.08$ & $86.11 \pm 7.53$ & 115.98 & 238.98 & 0.14 \\
\hline 9 & ST 09 & $523.1 \pm 63.73$ & $63.83 \pm 5.64$ & $66.31 \pm 10.88$ & 93.58 & 195.27 & 0.11 \\
\hline 10 & ST 10 & $814.13 \pm 99.68$ & $95.37 \pm 12.44$ & $115.15 \pm 12.63$ & 151.89 & 317.02 & 0.19 \\
\hline 11 & ST 11 & $601.91 \pm 44.88$ & $39.22 \pm 7.14$ & $55.63 \pm 2.45$ & 79.19 & 160.90 & 0.10 \\
\hline 12 & ST 12 & $645.83 \pm 46.09$ & $93.51 \pm 6.83$ & $99.18 \pm 3.94$ & 133.39 & 280.55 & 0.16 \\
\hline 13 & ST 13 & $637.68 \pm 65.16$ & $70.89 \pm 2.30$ & $71.94 \pm 5.80$ & 105.18 & 218.40 & 0.13 \\
\hline 14 & ST 14 & $672.19 \pm 18.24$ & $58.98 \pm 1.29$ & $64.96 \pm 3.31$ & 96.86 & 198.93 & 0.12 \\
\hline 15 & ST 15 & $565.52 \pm 23.18$ & $50.25 \pm 3.19$ & $70.69 \pm 13.86$ & 92.44 & 190.92 & 0.11 \\
\hline 16 & ST 16 & $656.65 \pm 23.83$ & $97.09 \pm 13.28$ & $79.62 \pm 8.95$ & 122.35 & 256.91 & 0.15 \\
\hline 17 & ST 17 & $667.94 \pm 45.27$ & $55.44 \pm 0.77$ & $42.21 \pm 0.51$ & 80.00 & 162.56 & 0.10 \\
\hline 18 & ST 18 & $641.14 \pm 5.19$ & $96.22 \pm 13.80$ & $105.79 \pm 9.32$ & 138.76 & 292.38 & 0.17 \\
\hline 19 & ST 19 & $554.02 \pm 22.74$ & $48.51 \pm 4.92$ & $46.6 \pm 2.34$ & 75.16 & 153.93 & 0.09 \\
\hline 20 & ST 20 & $503.78 \pm 25.81$ & $57.09 \pm 1.91$ & $50.49 \pm 14.97$ & 79.33 & 164.56 & 0.10 \\
\hline 21 & ST 21 & $457.66 \pm 25.58$ & $45.44 \pm 3.19$ & $42.3 \pm 3.85$ & 66.93 & 137.97 & 0.08 \\
\hline 22 & ST 22 & $775.33 \pm 58.25$ & $58.16 \pm 3.05$ & $58.76 \pm 1.60$ & 96.71 & 196.46 & 0.12 \\
\hline 23 & ST 23 & $409.99 \pm 28.88$ & $41.54 \pm 2.78$ & $35.58 \pm 0.98$ & 58.78 & 121.12 & 0.07 \\
\hline 24 & ST 24 & $682.86 \pm 42.23$ & $68.05 \pm 3.47$ & $56.13 \pm 6.70$ & 95.32 & 196.12 & 0.12 \\
\hline 25 & ST 25 & $626.37 \pm 24.30$ & $81.24 \pm 0.53$ & $73 \pm 11.10$ & 109.86 & 229.48 & 0.13 \\
\hline 26 & ST 26 & $614.23 \pm 13.26$ & $70.1 \pm 0.76$ & $75.03 \pm 4.30$ & 105.91 & 220.39 & 0.13 \\
\hline 27 & ST 27 & $536.03 \pm 16.40$ & $58.26 \pm 2.52$ & $84.48 \pm 6.45$ & 103.83 & 216.59 & 0.13 \\
\hline 28 & ST 28 & $564.59 \pm 5.92$ & $44.07 \pm 3.06$ & $37.85 \pm 3.08$ & 67.87 & 137.72 & 0.08 \\
\hline 29 & ST 29 & $520.04 \pm 13.09$ & $47.63 \pm 5.92$ & $67.53 \pm 15.47$ & 87.30 & 180.60 & 0.11 \\
\hline \multirow[t]{2}{*}{30} & ST 30 & $458.22 \pm 86.38$ & $53.44 \pm 7.86$ & $80.16 \pm 11.09$ & 95.61 & 200.14 & 0.12 \\
\hline & Average & 592.46 & 59.06 & 69.59 & 96.63 & 200.04 & 0.12 \\
\hline
\end{tabular}

\subsection{Absorbed Dose Rate in air}

The activity concentrations reported have been used to determine the absorbed gamma dose rate in air 1 $\mathrm{m}$ above the ground using the formula given below $[20,21]$.

$$
D_{R}=0.43 A_{U}+0.666 A_{T h}+0.042 A_{K} \ldots \text { (1) }
$$

Where, $A_{U}, A_{T h}$ and $A_{K}$ are activity concentrations of ${ }^{238} \mathrm{U},{ }^{232} \mathrm{Th}$ and ${ }^{40} \mathrm{~K}$ respectively. The calculated absorbed dose rate in air is given in figure (3). The absorbed dose rate in air ranges from $58.78 \mathrm{nGy} / \mathrm{hr}$ at station 23 to $151.89 \mathrm{nGy} / \mathrm{hr}$ at station 10 with an average of $96.63 \mathrm{nGy} / \mathrm{hr}$, which is a bit higher than the global average of $60 \mathrm{nGy} / \mathrm{hr}$ (range: 18-93 
nGy/hr) but does not pose any health threat or radiation risks [20].

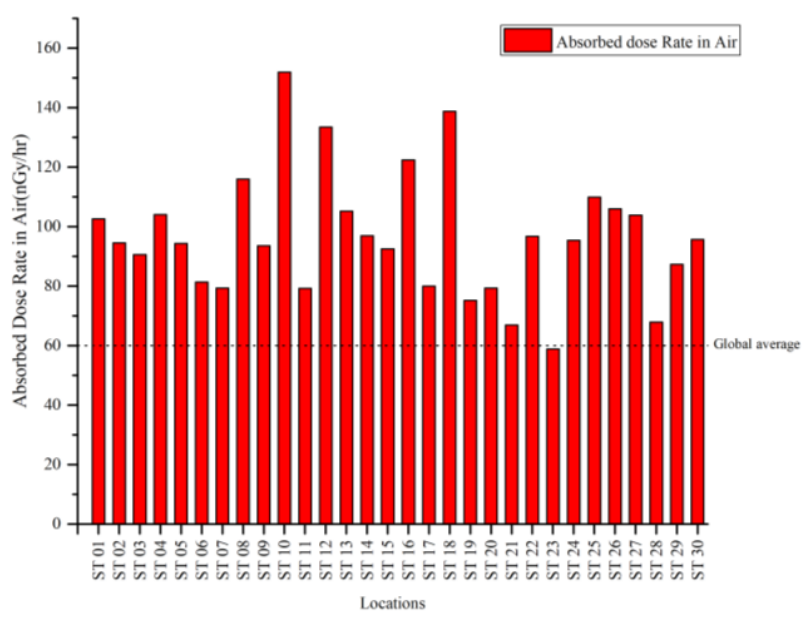

Fig. 3: Absorbed Dose Rate in air versus Location

\subsection{Radium Equivalent}

For the assessment of radiation hazard posed by these radionuclides in the soil samples, Radium equivalent or concentrations has been calculated using the following equation [22]. This radium equivalent is weighted sum of activities of ${ }^{40} \mathrm{~K},{ }^{238} \mathrm{U}$ and ${ }^{232} \mathrm{Th}$ radionuclides and is based on assumption that $4810 \mathrm{~Bq} / \mathrm{kg}$ of ${ }^{40} \mathrm{~K}, 370 \mathrm{~Bq} / \mathrm{kg}$ of ${ }^{238} \mathrm{U}$ and 259 $\mathrm{Bq} / \mathrm{kg}$ of ${ }^{232} \mathrm{Th}$ yield same gamma dose rate [23].

$$
R a_{e q}=A_{U}+1.43 A_{T h}+0.07 A_{k} \ldots
$$

Where, $A_{U}, A_{T h}$ and $A_{K}$ are activity concentrations of ${ }^{238} \mathrm{U},{ }^{232} \mathrm{Th}$ and ${ }^{40} \mathrm{~K}$ respectively.
As can be seen from figure (4) the radium equivalent of soil samples varied from 121.12 $\mathrm{Bq} / \mathrm{kg}$ to $317.02 \mathrm{~Bq} / \mathrm{kg}$ with an average value of $200.04 \mathrm{~Bq} / \mathrm{kg}$. The radium equivalent of all the soil samples is below recommended value of $370 \mathrm{~Bq} / \mathrm{kg}$ [22] and does not pose any radiation hazard.

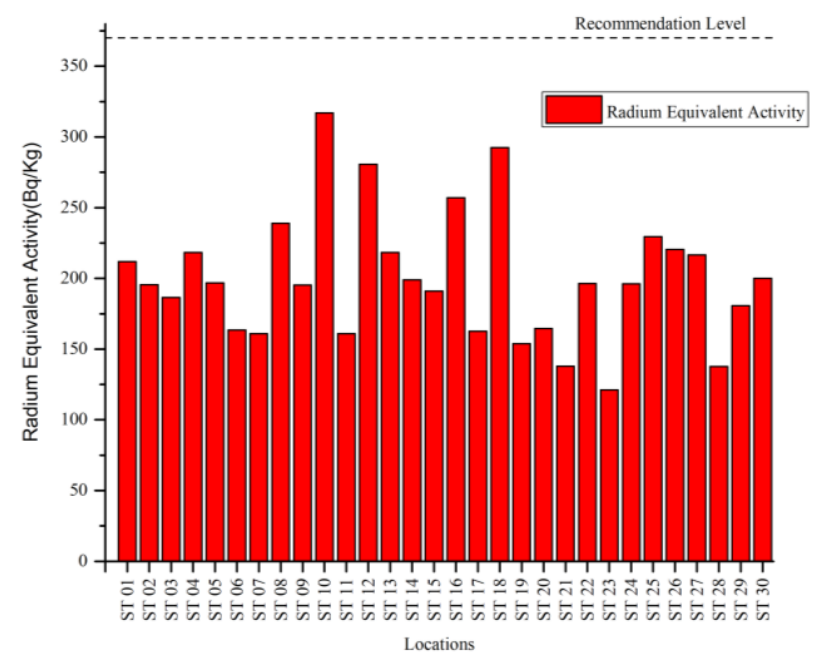

Fig. 4: Radium Equivalent of soil samples versus location

\subsection{Annual Effective Dose (AED)}

Considering the conversion factor for absorbed dose in air to effective dose and outdoor occupancy factor an annual effective dose equivalent has been calculated. Conversion factor of $0.7 \mathrm{~Sv} / \mathrm{Gy}$ and outdoor occupancy factor of 0.2 have been used for the calculations as per UNSCEAR reports [20]. The mathematical equation for calculating annual effective dose has been given below [24].

$$
A E D=D_{R}\left(n G y h^{-1}\right) X 8760\left(h_{\text {year }}^{-1}\right) X 0.2 X 0.7\left(S v G y^{-1}\right) X 10^{-6}
$$

Where, $D_{R}$ is dose rate as measured in equation 1 above.

The annual effective dose has been represented in the figure (5). According to the figure the minimum and maximum values for annual effective dose were $0.07 \mathrm{mSv} / \mathrm{yr}$ and $0.19 \mathrm{mSv} / \mathrm{yr}$ respectively with mean $0.12 \mathrm{mSv} / \mathrm{yr}$. This mean annual effective dose is 1.71 times that of world average value [20] and is lower than the $1.0 \mathrm{mSv} \mathrm{yr}^{-1}$ recommended by ICRP[25].

\subsection{External Hazard Index}

Since the soils of the location could be used for construction purpose, for evaluating the hazard of natural gamma radiation, external hazard index has been calculated using following equation [23].

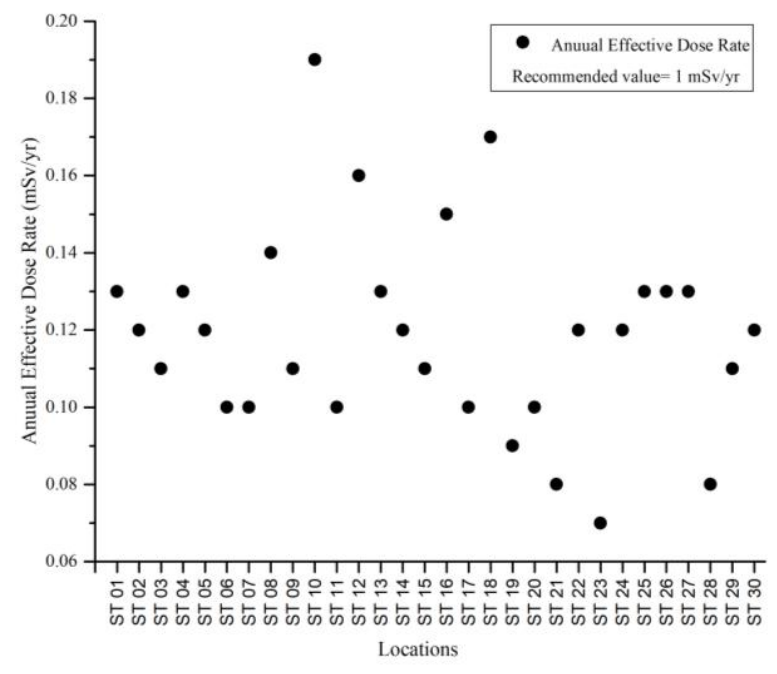

Fig. 5: Annual Effective Dose versus Location 


$$
H_{e x}=\frac{A_{U}}{370 B q K^{-1}}+\frac{A_{T h}}{259 B q K^{-1}}+\frac{A_{K}}{4810 B q K^{-1}}
$$

Where, $A_{U}, A_{T h}$ and $A_{K}$ are activity concentrations of ${ }^{238} \mathrm{U},{ }^{232} \mathrm{Th}$ and ${ }^{40} \mathrm{~K}$ respectively.

The external hazard indices for the soil samples have been given in figure (6). The highest, lowest and average values of the indices are $0.87,0.33$ and 0.55 respectively which are well below recommended level 1.

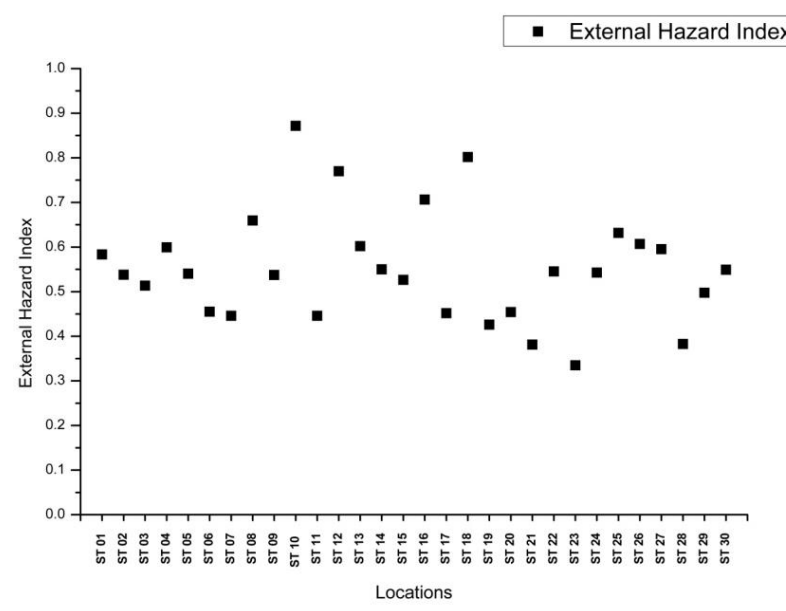

Fig. 6: External Hazard Index versus location

\section{CONCLUSION}

The average activity concentrations of the radionuclides ${ }^{40} \mathrm{~K},{ }^{238} \mathrm{U}$ and ${ }^{232} \mathrm{Th}$ in the soil samples are $592.46 \mathrm{~Bq} / \mathrm{kg}, 59.06 \mathrm{~Bq} / \mathrm{kg}$ and $69.59 \mathrm{~Bq} / \mathrm{kg}$ respectively. On the basis of these measurements, it seems that the distribution of natural radionuclides is variable. This study shows an increment in ${ }^{40} \mathrm{~K}$ concentration than previous study which might be attributed to excessive use of fertilizer and building materials contaminating the top soil. Activity concentrations of radionuclides were higher in soils from northern part in comparison to southern part of valley which might indicate presence of magmatic rock rich in uranium and thorium. In addition to the activity concentrations, the Absorbed Gamma Dose Rate in air, Radium Equivalent activity, Annual Effective Dose and External Hazard Index have been calculated for the soil samples. The calculated Hazard indices show that no radiological threat due to radionuclides on inhabitants of the study area. Further, this study has provided baseline information on the state of natural radioactivity in the study area which will serve as a reference for a future study.

\section{ACKNOWLEDGEMENT}

PL would like to thank Nepal Academy of Science and Technology (NAST) for providing lab facility to conduct this research.

\section{REFERENCES}

[1] Miah, F. K.; Roy, S.; Touchiduzzaman, M. and Alam, B. Distribution of radionuclides in soil samples in and around Dhaka City. Applied Radiation and Isotopes, 49(1-2): 133-137 (1998).

[2] Daulta, R.; Garg, V. K. and Singh, B. Natural Radioactivity in Soil, Associated Radiation Exposure and Cancer Risk to Population of Eastern Haryana, India. Journal of the Geological Society of India, 94(5): 525-532 (2019).

[3] Janković, M.; Todorović, D. and Savanović, M. Radioactivity measurements in soil samples collected in the Republic of Srpska. Radiation Measurements, 43(8): 1448-1452 (2008).

[4] Chikkur, G. C. and Umakantha, N. Half-life of thorium-232: a laboratory experiment. American Journal of Physics, 45(11): 1120-1122 (1977).

[5] Glendenin, L. E. and Steinberg, E. P. Fission Radiochemistry (Low-Energy Fission). Annual Review of Nuclear Science, 4(1): 69-80 (1954).

[6] Kelly, W. H.; Beard, G. B. and Peters, R. A. The beta decay of K40. Nuclear Physics, 11: 492-498 (1959).

[7] Shah, B. R. Rapid Determination of K-40 in samples of soil from within Kathmandu valley using multichannel spectrometer (Master's Thesis), Central Department of Physics, Tribhuvan University (1994).

[8] Shah, B. R. Preliminary study for the detection of K-40 in the soil samples of the Kathmandu district. In Proc. of $2^{\text {nd }}$ National conference on Science and Technology, RONAST, June 8-11, 1994, 769-774.

[9] Yadav, P.; Rajbhandari, P. and Shrestha, K. Estimation of Concentration of K-40 by Gamma Spectroscopy and Atomic Emission Spectroscopy in the Environmental Samples of Northern Kathmandu Valley. Journal of Nepal Chemical Society, 29: 75-80 (2013).

[10] Chetry, M. K.; Shah, B. R. and Pradhananga, T. M. ${ }^{137} \mathrm{Cs}$ Monitoring Using Lichens and Mosses from Kathmandu Valley. In Proc. III National Conference of Science and Technology, RONAST, Kathmandu, Nepal (1999).

[11] Wallova, G.; Acharya, K. K. and Wallner, G. Determination of naturally occurring radionuclides in selected rocks from Hetaunda area, central Nepal. Journal of Radioanalytical and Nuclear Chemistry, 283(3): 713-718 (2009).

[12] Abusini, M.; Al-Ayasreh, K. and Al-Jundi, J. Determination of uranium, thorium and potassium 
activity concentrations in soil cores in Araba valley, Jordan. Radiation protection dosimetry, 128(2): 213-216 (2008).

[13] Guidotti, L.; Carini, F.; Rossi, R.; Gatti, M.; Cenci, R. M. and Beone, G. M. Gammaspectrometric measurement of radioactivity in agricultural soils of the Lombardia region, northern Italy. Journal of Environmental Radioactivity, 142: 36-44 (2015).

[14] Retrieved from website, https://en.wikipedia.org/ wiki/Kathmandu_Valley, retrieved on 5 April, 2021.

[15] Muller-Lemans H. and van Dorp F. Bioturbation as a mechanism for radionuclide transport in soil: relevance of earthworms. Journal of Environmental Radioactivity, 31(1): 7-20 (1996).

[16] Arthur III, W. J. and Markham O. D. Small mammal soil burrowing as a radionuclide transport vector at a radioactive waste disposal area in southeastern Idaho. Journal of Environmental Quality, 12(1): 117-122 (1983).

[17] ORTEC, PMT Base with Integrated Bias Supply, Preamplifier, and Digital Multichannel Analyzer for NaI Spectrometry and Counting (2014).

[18] Singhal, R. K.; Basu, H.; Saha, S.; Kumar, A. and Pimple, M. Estimation of ${ }^{232}$ Th Concentration in environmental matrices by tracking activity of major daughter products $\left({ }^{212} \mathrm{Bi},{ }^{212} \mathrm{~Pb}\right.$ and $\left.{ }^{228} \mathrm{Ac}\right)$ with time in a hermetically sealed container. Journal of Environmental Analytical Chemistry. 3(4): 2380-2391 (2016).
[19] Hamby D. M. and Tynybekov A. K. Uranium, thorium, and potassium in soils along the shore of Lake Issyk-Kyol in the Kyrghyz Republic. Environmental Monitoring and Assessment, 73(2): 101-108 (2002).

[20] UNSCEAR, Sources and Effects of Ionizing Radiation, Report to the General Assembly, New York: United Nation (2000).

[21] Beck, H. L. Physics of environmental gamma radiation fields (1972).

[22] Beretka J. and Matthew P. J. Natural radioactivity of Australian building materials, industrial wastes and by-products. Health physics, 48(1): 87-95 (1985).

[23] Sivakumar R. An assessment of natural radioactivity levels and radiation hazards in the soil of Coonoor, South India. Environmental earth sciences, 72(12): 5063-5071 (2014).

[24] Ravisankar R.; Chandrasekaran A.; Vijayagopal P.; Venkatraman B.; Senthilkumar G.; Eswaran P. and Rajalakshmi A. Natural radioactivity in soil samples of Yelagiri Hills, Tamil Nadu, India and the associated radiation hazards. Radiation Physics and Chemistry, 81(12): 1789-1795 (2012)

[25] ICRP, Recommendations of the International Commission on Radiological Commission, ICRP Publication 60, Pergamon Press. New York (2000). 